\title{
Detecting development scenarios of dynamic events in electric power network smart-grids. Part two "Selective Protection"
}

\author{
Vitaliy F. Sivokobylenko ${ }^{1)}$ \\ ORCID: https://orcid.org/0000-0002-7720-0540; svf1934@gmail.com. Scopus Author ID: 6603906155 and 55553493200 \\ Andrey P. Nikiforov ${ }^{2)}$ \\ ORCID: https://orcid.org/0000-0002-3724-430; a.p.nikiforov@i.ua. Scopus Author ID: 57191825673 \\ Ivan V. Zhuravlov ${ }^{3}$ \\ ORCID: https://orcid.org/0000-0003-4879-4666; ivanvzhuravlov@gmail.com \\ 1) Donetsk National Technical University, 2, Shybankova Square. Pokrovsk, Donetsk region, 85300, Ukraine \\ 2) Education and Research Institute of Energetic, Automation and Energy Efficiency, \\ National University of Life and Environmental Sciences of Ukraine, 12, Heroiv Oborony Str, building 8, Kyiv, 03041, Ukraine \\ 3) SICAME SAS France, 39 Ave, du Midi, St. Sornin Lavolps, France
}

\begin{abstract}
When implementing development concepts in the electric power industry (such as "Smart Grid", "Digital substation" and "Outsourcing of services"), the task of ensuring stable relay protection operations and automation devices is urgent. The problem is solved according to the developed structural-information (SI) method. A method for selective search of the optimal amount of structured information for automatic decision-making is proposed. The article discusses an algorithm for recognising scenarios for the development of semantic events, which is included in the SP-method. The algorithm is applied uniformly for all hierarchical levels of recognition, based on the goals of decision making at the senior level. Control of the sequence of information events is performed in the dynamics of the passage of events along one path from all relationships according to the structural-information model. Part 1 shows a collaborative structural-information model consisting of a shaping tree in a dynamic object and a recognition tree in devices. A theoretical description of the algorithm is given using the amplitude and time $(\Xi, H)$ selectivity windows in the general structural scheme of S-detection. The application of the method for different hierarchical levels of recognition is shown. The decision-making results are presented in two forms, by means of a single semantic signal to indicate a group of results and filling in the table of the sequence of occurrence of the recognised elementary information components. Part 2 shows the application of the SPmethod at different hierarchical levels of recognition for the synthesis of a selective relay, which implements an algorithm for finding a damaged network section with single-phase ground faults in 6-35 kV distribution networks with a Petersen's coil. The reasons for the unstable operation of algorithms of known selective relays are indicated, based on the concepts of scenario recognition. The improvement of the structure of a selective relay operating on the basis of the criterion for monitoring the coincidence of the first half-waves of the mid-frequency components in the signals of transient processes is considered. Examples of the synthesis of elementary detectors of absolute, relative and cumulative actions in relation to a selective relay are given, which make it possible to fill the amount of information for general S-detection. The simulation of the operation of the synthesised S-detector on the signals of real emergency files of the natural development of damage to the isolation of the network phase and simulation of artificial scenarios of events in the mathematical SI-model are carried out.
\end{abstract}

Keywords: Relay protection; automation; smart grid; single-phase; earth faults; semantic signal; structural-information

For citation: Sivokobylenko V. F., Nikiforov A. P., Zhuravlov I. V. Detecting development scenarios of dynamic events in electric power network smart-grids. Part two "Selective Protection". Applied Aspects of Information Technology. 2021; Vol. 4 No.4: $311-328$. DOI: https://doi.org/10.15276/aait.04.2021.2

\section{INTRODUCTION}

The implementation of modern concepts for the development of the electric power industry implies the presence of a method of operating with elementary information components for the shortest possible receipt of semantic conclusions when solving problems of automatic decision-making [1, 2], [3, 4]. The use of well-known inertial methods for processing signal information, based on the representation of input signals $U_{I N}(t)$ with circular frequencies $\omega$, requires further interpretation of the results obtained $[5,6]$.

(C) Sivokobylenko V., Nikiforov A., Zhuravlov I., 2021

This is an open access article under the CC BY license (http://creativecommons.org/licenses/by/3.0)
This is critically manifested in the conditions of limiting the amount of input information $Q$ during short-term, irregular information events in the input signals $U_{I N}(t)$ of relay protection and automation (RPA) devices for automatic decision-making [4, 7].

The problem of automatically obtaining dynamic semantic conclusions is solved by ensuring the stability of the operation of a selective earth fault protection relay (EFP) in distribution networks with a voltage of $6-35 \mathrm{kV}$ and a arc suppression Petersen's coil (Fig. 1) [6, 7], [8, 9]. Such an dynamic object of control and protection (OCP) is characterised by low currents of EFP, the ability of 
high-voltage insulation to self-recovery, changes in the parameters of selective signals in different networks, as well as the variety of semantic situations $S N$ and their scenarios SceN following during the development of EFP, the presence of thirdparty transient processes [4]. The listed properties of the control and protection object (OCP) lead to the need to solve the problem of ensuring the stability of the relay algorithm at the level of recognition of dynamic semantic events [4].

The time for making a decision $T_{C H E C K}$ from the moment of the beginning of the development of the EFP to the moment of issuing the resultant signal of the relay operation, can be very long, e.g. $T_{C H E C K}=0.1-1.5 \mathrm{~s}$ and can last up to 4 hours $[10,11]$, $[12,13],[14,15],[16,17]$. The time $T_{\text {CHECK }}$ can be automatically reduced, depending on the meaning of the events occurring and the possibility of stable formation of the results of the relay operation [4]. During the time $T_{C H E C K}$, it is possible to develop a complex sequence and combination of breakdowns of the EFP at the initiating section of the network, which can be systematised in the form of an SImodel.

For example, one of the SceN scenarios for the development of events according to the SI-model, can consist of semantic situations $S N$ :

a) $S 1$ "NM start";

b) $S N$ "Metal EFP";

c) $S N$ "Skew";

d) $S N$ "Short-term short-circuit"; $S N$ "The first half-wave EFP";

e) $S N$ "Self-liquidating breakdown of EFP";

f) $S N$ "Large values of voltages on healthy phases of the network";

g) $S N$ "Occurrence of a number of breakdowns of the EFP on the damaged section of the network";

h) $S c e N$ "NM termination" [14, 15], [16].

Examples of other scenarios are: a) $\mathrm{SceN}$ "Breakdown of weak points in network isolation";

b) SceN "Self-liquidation of the EFP";

c) $S c e N$ "Transition of the EFP to an undamaged section of the network";

d) SceN "Interphase short circuit with disconnection of the section after $0.5 \mathrm{~s}, 1 \mathrm{~s}$ ";

e) $S c e N$ "Transition of EFP to short circuit SC" and other SceN scenarios.

Part 1 of the article shows that scenarios for the development of SceN can be described by a sequence of logical changes in the recognised elementary situations $S N$, e.g. $S c e 1=(S 1, S 2, \ldots S N)$. A high-voltage power grid can be in a state of one of the semantic situations $S N$ for a long time.

These $S c e N$ scenarios are typical OCP scenarios and should have their own names. For example, the scenario Sce10 "Multiple self-destructive EFP" = (S1 "NM start", S3 "Self-destructive Peck", S3 "Self-destructive Peck", $S 2$ "NM end") can be shortened to $S c e 10=(S 1, S 3, S 3, S 2)$. Such $S c e N$ are included in the training set of EFP alarms for the synthesis and improvement of RPA algorithms [14, 15], [16].

In Part 1, it is shown that the problem being solved has insufficient information, regarding volume $Q$ for the stability of automatic decisionmaking during recognition [3, 4], [5]. OCP should be described as a dynamic object with sequential consideration in the steps of $n, n+1, N$ used to develop elementary information events [4].

To eliminate the causes of unstable operation of the selective relay $[4,19]$, a structural-informational (SI) method proposed, based on two theorems: "On the presence of a semantic signal in relay protection and automation devices" and "On the unity of the description of structural diagrams in relay protection and automation devices" $[4,5]$. SI-method operates with elementary information components as

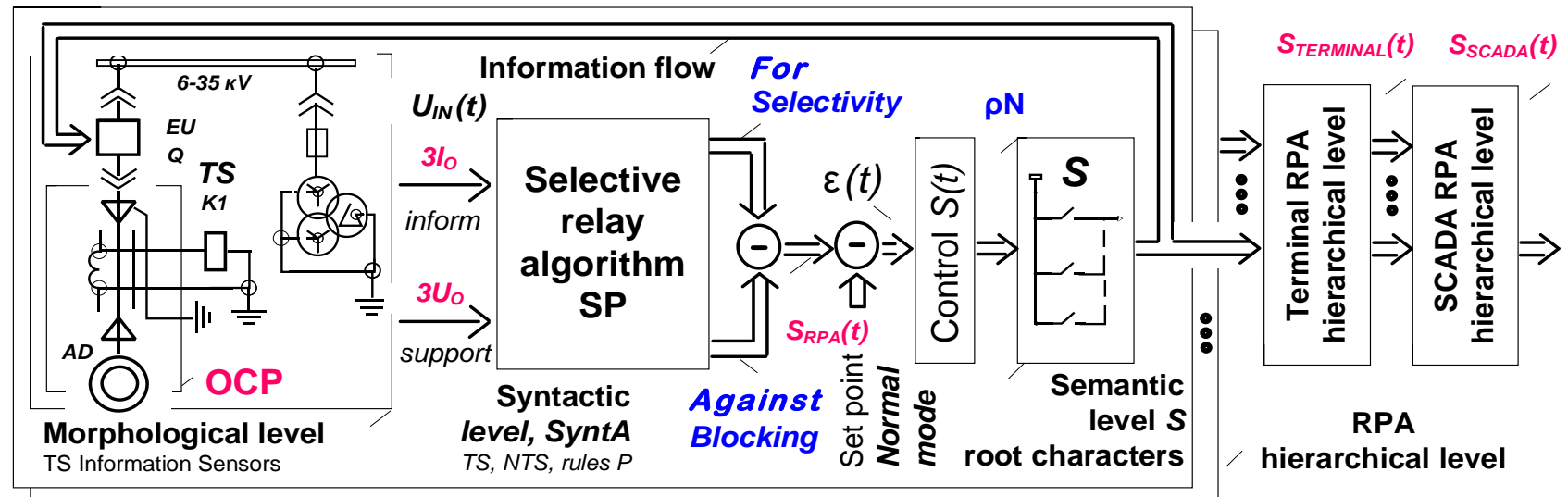

Fig. 1. An example of a typical RPA scheme of motor AD one of the sections of the 6-35 $\mathrm{kV}$ network. Representation of information flows during the formation of a semantic signal $S(t)$ in the ASNOM system

Source: compiled by the authors 
linguistic variables, for the sake of accuracy, specific names, abbreviations, abbreviations, chains of constituents, as well as logical relationships between them, are indicated in the text.

Furthermore, the paper shows the application of the SceN scenario recognition algorithm in the selective search (SP) method for the optimal amount of information $Q$ for decision-making. The algorithm is applied uniformly for all hierarchical levels of recognition: sensor, relay, terminal, and SCADa.

ANALYSIS OF LITERARY DATA. IMPROVEMENT OF THE ANALYSIS OF THE
STRUCTURES OF THE ALGORITHMS OF
SELECTIVE PROTECTION

In previous publications, the $\Psi$-structures of algorithms for detectors of known RPA devices were compiled and an analysis of their capabilities was given $[4,5],[6]$. It is shown that the well-known RPA recognition algorithms are often based on the analysis of only one or several $S N$ situations, to which the variety of development of the process of insulation damage in the network is reduced [19]. In other $S N s$, the algorithms are blocked and do not recognise the change of $S N$ and $S c e N$ scenarios. This causes the algorithms to detect the resulting root symbol S of the generalised recognition tree (GES) of devices with a limited number of elementary information components but insufficient selectivity and operational stability for operational practice (Fig. 2, Fig. 3 and Fig. 4 of Part 1).

Considering the most common reasons for the instability of the operation of the known algorithms for determining the damaged section of the network during EFP (based on the task of detecting SceN) in more detail:

a) The initial level of TS formation. During the development of the known selective relays, the most attention was paid to the operation of the $U_{I N}(t)$ input signal filters. The formulation of the main task of the filters (to isolate selective components) turned out to be insufficient. Therefore, the use of signal filters based on the concepts of circular frequency $\omega$ should be limited to the task of eliminating higher frequencies relative to the selective interference components in the signals $U_{I N}(t)$ in order to minimise the filter inertia.

In the known relays, to fill the amount of information $Q$, a cumulative time-pulse criterion is used which, which during the time $T_{C H E C}$ controls the excess of the selective signal level of the set value of the threshold element with hysteresis. But, according to the simulation, the criterion is effective only in the case of a regular repetition of semantic events specified in the relay. However, with short-term irregular events, the criterion does not correspond to the problem being solved [10], [11, 12], [13, 14], [15, 16], [17, 18], [19, 20].

In the MorphA machine, detection is performed at one point by synchronous phase detectors (SFD), there is no selectivity-time $\mathrm{H}$-window. The minimum number of rules for blocking the $P B$ of the algorithm is implemented, or the rules of the $P B$ may be absent. There are no TS sensors for the formation of primary elementary additional, verification, confirming information. There are no $P B$ rules for controlling the beginning and the end of the transition process in the OCP.

Methods for assessing the sufficiency of individual TS and NTS elements, for the recognition problem in a particular OCP, have not been implemented. This will not allow adjusting relay algorithms based on operating experience and expecting robustness of detection. The absence of a difference in SceN leads to false alarms of unlocked relays in undamaged sections of the network at the beginning of the development of the processes.

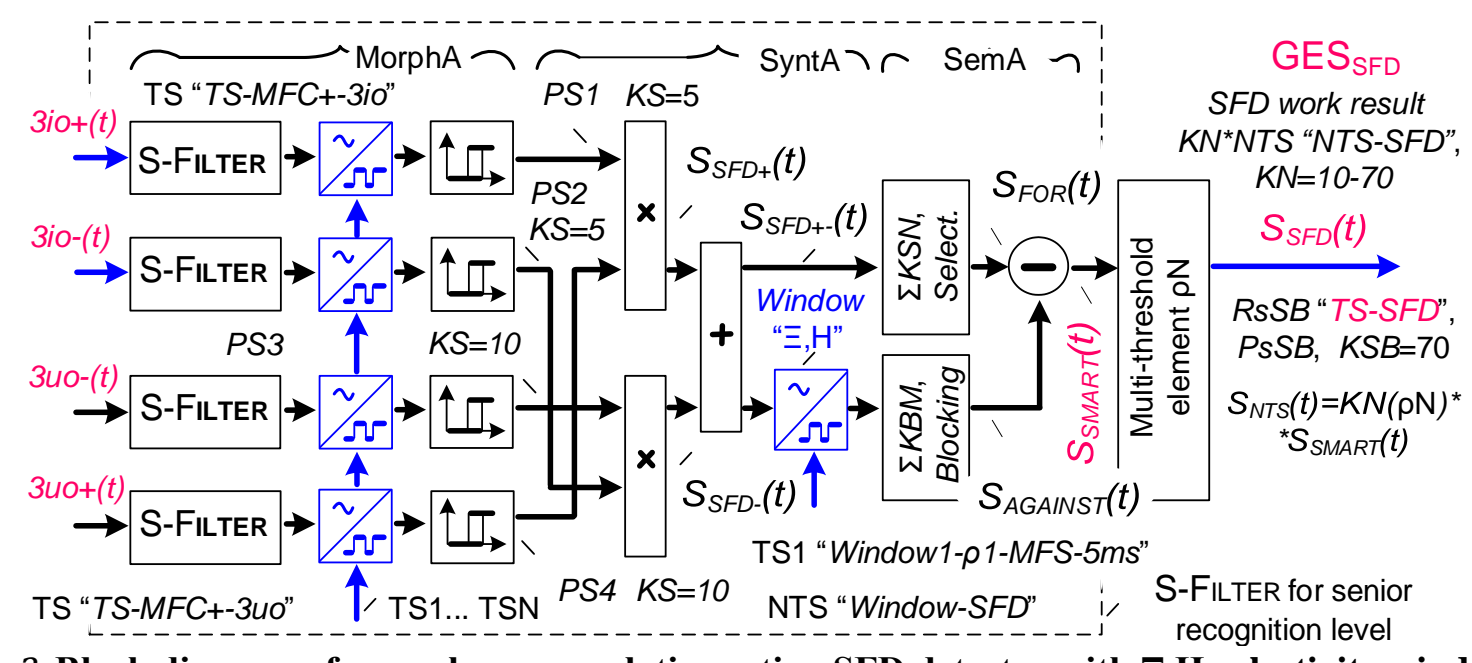

Fig. 2. Block diagram of a synchronous relative action SFD detector with $\Xi, \mathrm{H}$-selectivity windows Source: compiled by the authors 
b) The level of formation of SN situations. The operation of the relay algorithms is blocked after the initial selection of only one SceN scenario, other informational events are not considered. In the case of other SNs, when damage develops in the OCP, the algorithms are blocked and do not recognise the $S N$ change, SceN scenarios. All SNs differ in their residuals, after the initial selection of only one SceN scenario, the others are not considered. The same happens in all intact areas of the OCP.

c) The scripting level SceN. When a significant part of the non-selective operation of RPA devices occurs, the lack of the necessary amount of information $Q$ for decision-making is critically manifested. This is a consequence of the limited or lack of appropriate $P N$ rules in the recognition A algorithms.

Consequently, such algorithms cannot distinguish between most of the semantic $S N$ and SceN scenarios. At the same time, the available information in the input signals $U_{I N}(t)$ and partially recognised information in devices in cases of interruptions in the development of EFP, are not used (Fig. 1) [4, 20], [21, 22], [23, 24], [25]. Modelling of the relay algorithms shows that a change in $S N$, SceN allows the extraction of additional information and uses additional $P_{A D D}$ rules in recognition algorithms [26, 27], [28].

\section{GOALS AND OBJECTIVES OF THE RESEARCH}

In Part 1 of the work, it is shown that, in order to increase the stability of the RPA devices, it is necessary to use all of the available information $Q$ that can be obtained during the operation of the RPA devices [22, 24], [24].

For this purpose, it was necessary to solve the problems of forming an additional volume of $Q$ by:

a) using the theoretical description of SI-models based on the recognition of elementary information components in $U_{I N}(t)$ signals with irregular information events;

b) implementing block diagrams of devices, based on methods of dynamic recognition of $U_{I N}(t)$ signals;

c) forming accumulated information redundancy during signal processing, to eliminate recognition errors. It is known that the redundancy of information allows working with distortions, extraneous signals, interference, etc;

d) transfer of information about the amount of information $Q$ to the higher information levels of recognition by means of the weight coefficient $K N$;

e) minimisation of the complexity of synthesised structures and recognition algorithms; f) taking into account the influence of different operating conditions of specific sections of the OCP, when introducing devices with the same algorithms.

The synthesis of the recogniser algorithm should be focused on recognising the SceN scenarios at all hierarchical levels of the recognition tree, in the general hierarchy of signal generation processes in OCP.

The aim of the work is to synthesise methods for obtaining an additional amount of information $Q$ to eliminate the causes of violation of the stability of recognition with dynamically changing information and automatic decision-making in selective protection devices OCP (see Part 1). To eliminate the causes of instability, you must, cases of similarity of basic $S N$ situations with jamming, unrecognisable $S N s$ in structure and content should be highlighted first of all $[27,28]$. Also, the specifics of the operation of the same algorithm in the dynamics of the development of processes for undamaged sections of the network should be taken into account. Signals from undamaged areas can have unexpressed informational components, which, with further development of the EFP, can lead to unlocked relays to unstable operation (Fig. 1). Therefore, it is important to systematise possible SceN scenarios and their typical change for intact sections of the network.

And also, when operating at long time intervals, the recognition algorithm should be able to take into account the total and accumulated amount of information $Q$ for each specific relay in the dynamics of the development of the transient process.

\section{RESEARCH METHODS: SYNTHESIS}

To synthesise the structure and algorithm of the selective relay of protection against EFP, we will consider the synthesis of criteria for dynamic recognition of SceN scenarios, SN situations (Fig. 7 of Part 1). We will focus on the S-filtering of structural dynamic events in the signals $U_{I N}(t)$ of transient processes in the network, to isolate selective and blocking TS elementary information components.

In Part 1 of the work, a criterion for the selectivity of RPA devices for dynamic objects is formulated, based on the delegation of S-detection of SceN scenarios from the upper hierarchical level to all subordinate levels. The criterion of selectivity being developed is named as "Selective search SP of the optimal amount of information $Q$ to determine the damaged section of the network".

Also in Part 1, an assessment is made of the conditions of need and sufficiency of the amount of 
information were assessed $Q$ are evaluated for automatic decision-making when the semantic Sdetector is operating. The result is the recognition of SceN scenarios for the dynamic development of $S N$ semantic situations. The possibility of disconnecting the damaged section of the network, forming the protocol of the relay operation, is determined.

Control of the sequence of occurrence of elementary information events is performed by $\Xi, \mathrm{H}$ windows of selectivity for amplitude parameters " $\Xi$ " and time parameters " $\mathrm{H}$ " by tracking the motion of a point attractor (Attr) along the trajectory of development of the signals $U_{I N}(t)$. As a result, the sequence of appearance of TS, NTS in the chain of events, is formed.

The recognition decision is made on the basis of the formation of a semantic signal $S(t)$, which reflects the passage of elementary information components through the GES structural schemes. In this case, the passage is allowed or blocked by the corresponding $\Xi, \mathrm{H}$-window (Fig. 3).

As a result of the consistent application of the method, it turns out that at the initial hierarchical level of Morph, its own $\Xi$,H-windows work, for the older SyntA, its own $\Xi, \mathrm{H}$-windows work, and so on. To a higher hierarchical level, data on the achieved value of the amount of information $Q$ is transmitted by weight coefficients $K N$ in the range, for example, $K N=1-5$, depending on the completeness of the development of selective components in the input signals $U_{I N}(t)$.

The S-detector produces one of a series of responses with the corresponding resulting weights $K N$. This makes it possible to combine S-detectors of lower hierarchical levels into sequential chains by means of a common semantic signal $S(t)$ at different hierarchical levels of recognition: morphological, syntactic, and semantic.

The synthesis method for the algorithm for accumulating a sufficient amount of information $Q$ is implemented as follows. The high frequency recorder (VCR) records the real OCP signals in the emergency files. SN, SceN are detected, with operational errors in the elementary and general criteria of relay actuation. The relay signal posters show the recognition of the path passing from one SceN scenario to another, according to the GES recognition trees. The errors found are eliminated by improving the $P S$ selective and $P B$ blocking rules in the generalised equivalent tree of $\mathrm{GES}_{\mathrm{RPA}}$ device recognition.

During operation, the relay itself generates a protocol for operation with the results of triggering elementary information events and fixing the $U_{I N}(t)$ signals. If necessary, such a protocol and the quality of the relay algorithm can subsequently be checked remotely when the received signals from the emergency files are submitted to the mathematical model of the relay in CAD in manual or automatic mode. Based on this, storage devices and information transfer channels are initially used in the design of devices. Thus, the concept of development of the electric power industry "Outsourcing of services" is implemented [4, 5], [27].

\section{RESEARCH MATERIALS. DELEGATION OF THE SCENE RECOGNITION METHOD TO THE INITIAL RECOGNITION LEVEL}

A block diagram of a selective relay can be synthesised, implementing the introduced operation criterion. Let us consider the construction of elementary amplitude (AD) and synchronous SFD phase detectors for filling the volume $Q$ when implementing the method of S-detection of the available signal in a selective relay.

The block diagram of the relay and the Sdetector algorithm is built on the basis of a sequential, hierarchical nesting of the structures described in Part 1 and Part 2 of this work.

a) Choose the central point of the hierarchical levels of recognition, the GES RPA scheme (Fig. 4, Fig. 5 and Fig. 6 of Part 1). The synthesised S-detector circuit is a series connection of a selective S-filter

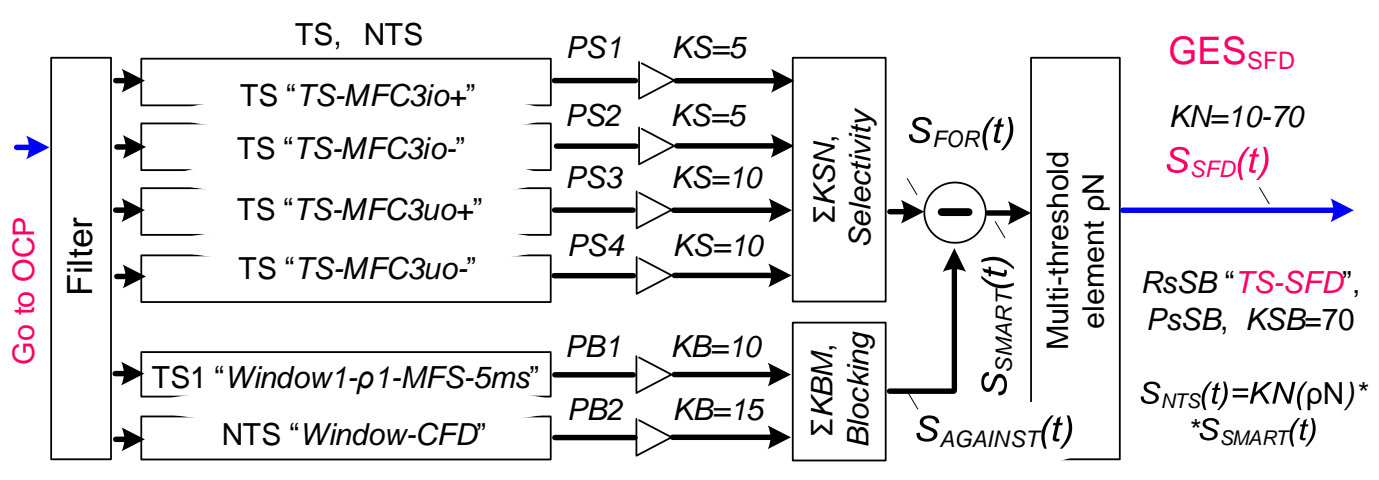

Fig. 3. The semantic part of the synchronous-phase type S-detector Source: compiled by the authors 
and a multi-threshold element $\rho$ N. In Fig. 2, Fig. 4, Fig. 5 and Fig. 7 of Part 1, shows a block diagram of a general S-detector and an algorithm for its operation, which includes different levels of the recognition hierarchy. The SceN scenario detector is added to the S-filter structure in Fig. 7 of Part 1.

b) Consider the construction of a general structural diagram of a selective relay towards the senior and lower hierarchical levels of recognition $\mathrm{GES}_{\mathrm{SCADA}}==\Sigma \mathrm{GES}_{\mathrm{RPA}}=\Sigma \mathrm{GES}_{\mathrm{TS}}$ (Fig. 5 of Part 1). For example, in Fig. 1 of Part 1 and in Part 1 of Part 2 shows the construction of the general structural diagram of the relay towards the senior hierarchical level of recognition (semantic level) $\mathrm{GES}_{\text {TERMINAL }} \rightarrow$ GES $_{\text {SCADA }} \rightarrow$ GES $_{\text {ASNOM. }}$. In the direction of the junior hierarchical level (morphological level), the construction of the circuit is shown in Fig. 5 of Part 1, which show the GESTS circuits and the algorithm of the amplitude elementary detector using the example of selective high-medium frequency components (HFC-MFC) of $U_{I N}(t)$ signals.

c) The form and result of the common $\Xi, \mathrm{H}-$ window, and the presence of the output threshold element $\rho \mathrm{N}$ in the S-detection algorithm of SceN scenarios, are shown in Fig. 6 of Part 1.

At this level, as well as at each, hierarchical level of the S-detector operation, a semantic signal is formed $S(t)$ is formed, which is controlled by the multi-threshold element $\rho \mathrm{N}$ (Fig. 1, Fig. 2, Fig. 3 and Fig. 4). When the element $\rho \mathrm{N}$ is triggered, the result is assigned the corresponding weighting factor $\mathrm{TS}=K N^{*} \rho \mathrm{N}$. There can be, for example, five values of the coefficient of significance of the result $K N$ from the range $K l=5 \ldots K l=100$ (Fig. 1). This makes it possible to take into account the significance of the result for its use at a higher level of recognition and transfer of significance to the upper level of recognition by accumulating the signal level $S(t)$.

d) When synthesising the SP-algorithm, the greatest attention is paid to the recognition of $S N$ situations and scenarios SceN "Not associated with EFP", $S N$ "Extraneous processes", and $S N$ "Interference". In the rest, the situation $S N$, not known to the automaton A, will be defined as $S N$ "Unrecognisable". The reference to this $S N$ is the basis of recognition theory.

For example, in the structure of the well-known relay in Dudarev (1978, Ukraine) [19], the main selective criterion is "Comparison of the signs of the first half-waves of the mid-frequency components 3io, 3uo".

Let us consider the synthesis of elementary information sensors TS of the initial hierarchical recognition level, based on the tasks set. Detectors of absolute, relative and cumulative actions are widespread. It is known that when processing information, the most stable working is the sensor of relative action.

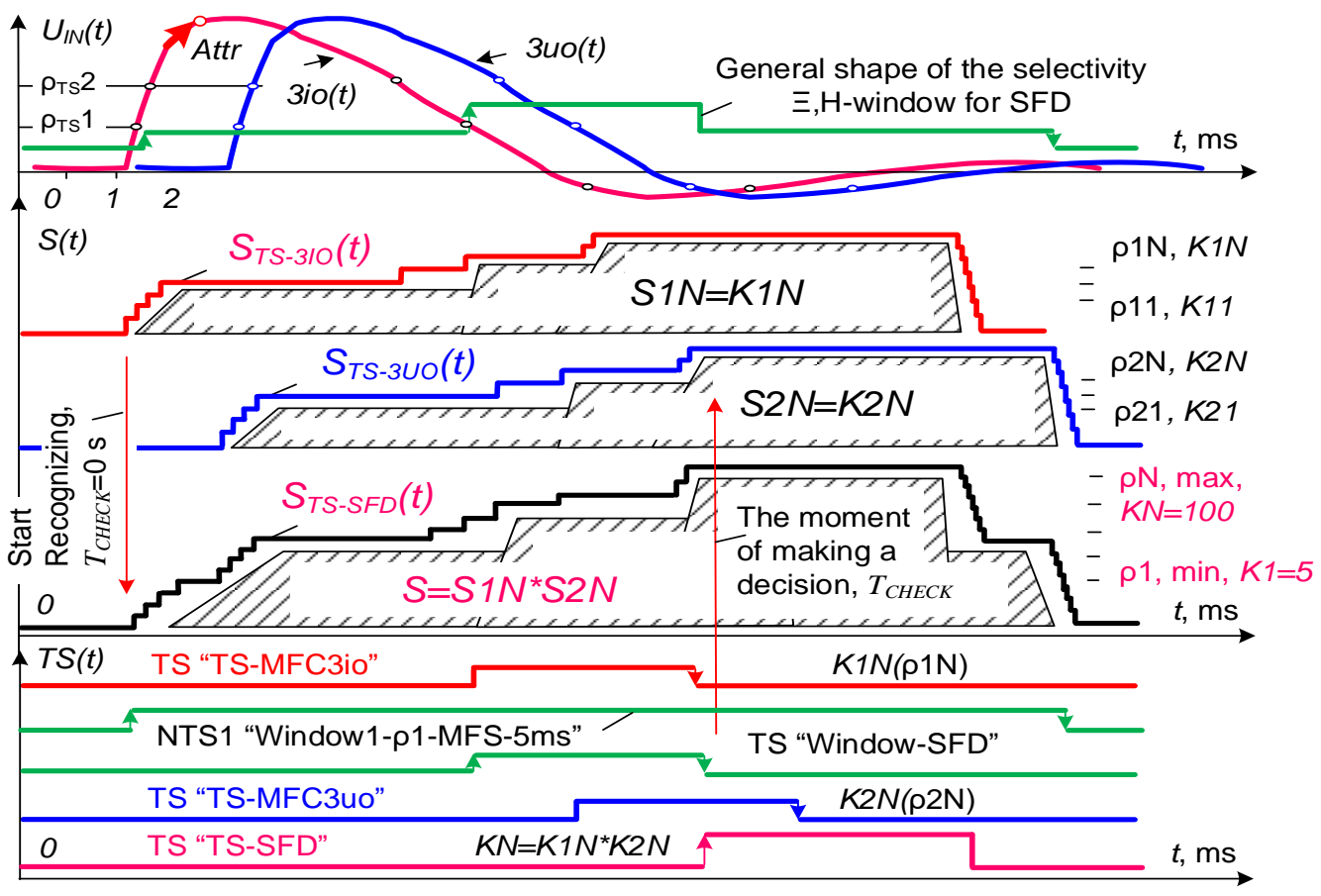

Fig. 4. The principle of operation of the synchronous-phase type S-detector circuit Source: compiled by the authors 
The cumulative action sensor is used when it is possible to organise the observation time. The absolute action sensor is the least noise-resistant and is used when there is no possibility to apply other methods.

\section{SYNTHESIS OF A RELATIVE ELEMENTARY S-DETECTOR}

Any directional relay is built according to the relative method of information processing, which allows comparison of the information "3io" and reference "3uo" input signals $U_{I N}(t)$ (Fig. 2). Let us consider the description of the semantic S-detection algorithm for the implementation of the relative action of the phase-synchronous detector (SFD) and for the formation of the $\Xi, \mathrm{H}$-selectivity window "Duration of the first half-waves of the HFS-MFS" or " $\mathrm{H},+3 \mathrm{io},+3$ uo".

To compare the coincidence of the signs of the information components of the first half-waves of positive +3 io, +3 uo or negative -3 io, -3 uo, the internal structure of the relative detector is divided into the corresponding two parts. Consequently, such a general structure of a synchronous detector SFD will be preserved for all relay algorithms in view of the generality of concepts: elementary information components, a relative way of comparing information $U_{I N F O R M}$ and reference $U_{\text {SUPPORT }}$ signals (Fig. 3), as well as filters for preparing input signals $U_{I N}(t)$ (Fig. 4 of Part 1).

Figure 3 shows the syntax level SyntA of SFD recognition. The trajectory of motion of the point attractor Attr "SFD", according to the resulting semantic signal $S_{S F D}(t)$, is controlled by the corresponding $\Xi, \mathrm{H}$-windows of selectivity SFD, as shown in Fig. 4.

The result of the work of the semantic signal $S_{T S-S F D}(t)$ operation of this S-detector SFD is cumulative until a decision is made. This makes it possible to implement multi-point SFD detection and prepare information for decision-making at the higher hierarchical levels of recognition. Resulting signal $S_{T S-S F D}(t)$ is estimated by a number of threshold values (e.g. $\rho \mathrm{N}, \mathrm{N}=1 \ldots 5$ ) and weight coefficients $(K N, \mathrm{~N}=1 \ldots 5)$, corresponding to the achieved significance of the result $K N=K 1 N^{*} K 2 N$ when issuing TS "TS-SFD".

Improvement of the structural diagram and operation algorithm of this main selective S-detector SFD in the relay concerns the formation of information components (TS) for the comparison circuit " $x$ " and obtaining the results of the operation of the structural blocks " $\Xi, \mathrm{H}$ ", based on ensuring the stability of the relay in real operating conditions (Fig. 4).

\section{SYNTHESIS OF ELEMENTARY AMPLITUDE S-DETECTOR}

Amplitude detector AD is the initial TS symbol when detecting occurrences in the input signals $U_{I N}(t)$. Its task is to prepare the initiating TS for starting the sequence of $\Xi, \mathrm{H}$-selectivity windows. Other absolute action TS information sensors are constructed in a similar way. In Fig. 5 shows the scheme of the beginning of the recognition of the $S N$ situation in the $S c e N$ tree, which describes the work of the morphological automaton MorphA (Fig. 3 of Part 1). The scheme of the semantic automaton SemA is shown in Fig. 6.

Let us consider the synthesis of an algorithm for semantic S-detection of AD amplitude components for the formation of the $\Xi$,H-window "Two amplitude thresholds and one time window" or " $2 \Xi, \mathrm{H}$ ". To protect against signal interference, elementary S-detectors are blocked in the initial state. The AD algorithm begins with a history, which is the $S N$ situation "Normal mode. Start". Only the "Initiating" amplitude selective $\Xi$-window operates in the $\mathrm{AD}$ detector. Its task is to prepare the "Initiating" TS for launching a sequence of $\Xi, \mathrm{H}-$ windows of selectivity. Further, on the leading edge of the triggering terminal symbol TS1 "MFCThreshold-pTS1", the NTS2 window "MFCWindow2 $\Xi+-H-\rho T S 1-W a w 1 "$ opens.

Furthermore, in the designation of the TS name "HFC 3io+/-", at the place of the first sign position, an increase in "+" or a decrease in "_"“, is indicated based on the trajectory of motion of the point Attr attractor of the signal $U_{I N}(t)$ and the considered selective component (Fig. 5).

For example, scenarios Scel "The trajectory of motion of the point attractor Attr along the rising edge of the input signal $U_{I N}(t)$ exceeds threshold No.1 in the $\Xi$-window "Initiating"'. The algorithm identifies the following sequence of events namely.

Upon the fact that the signal $U_{I N}(t)$ exceeds the threshold "MFC3io+/+, threshold No. 1", TS "Initiating" is formed, then two-time $\mathrm{H}$-windows are formed with a duration of $t_{\text {WINDOW }}=5 \mathrm{~ms}$ for the rising edge of $U_{I N}(t)$ and with a duration of " $\mathrm{H}$ " ... This leads to the appearance of TS "MFC+/+, threshold No. 2" during the duration of $t_{\text {WINDOW, }}$, then TS "Resulting", TS "MFC3io+/+" is formed. The appearance of these TS forcibly closes the $\Xi$-window "Initiating" and, accordingly, to the closure of the temporary part of the H-window "Initiating". If the value of the signal $U_{I N}(t)$ does not exceed the amplitude $\Xi$-threshold No. 2 the TS "Initiating" symbol is not formed, and the $\Xi, \mathrm{H}$-windows are self-closed. 


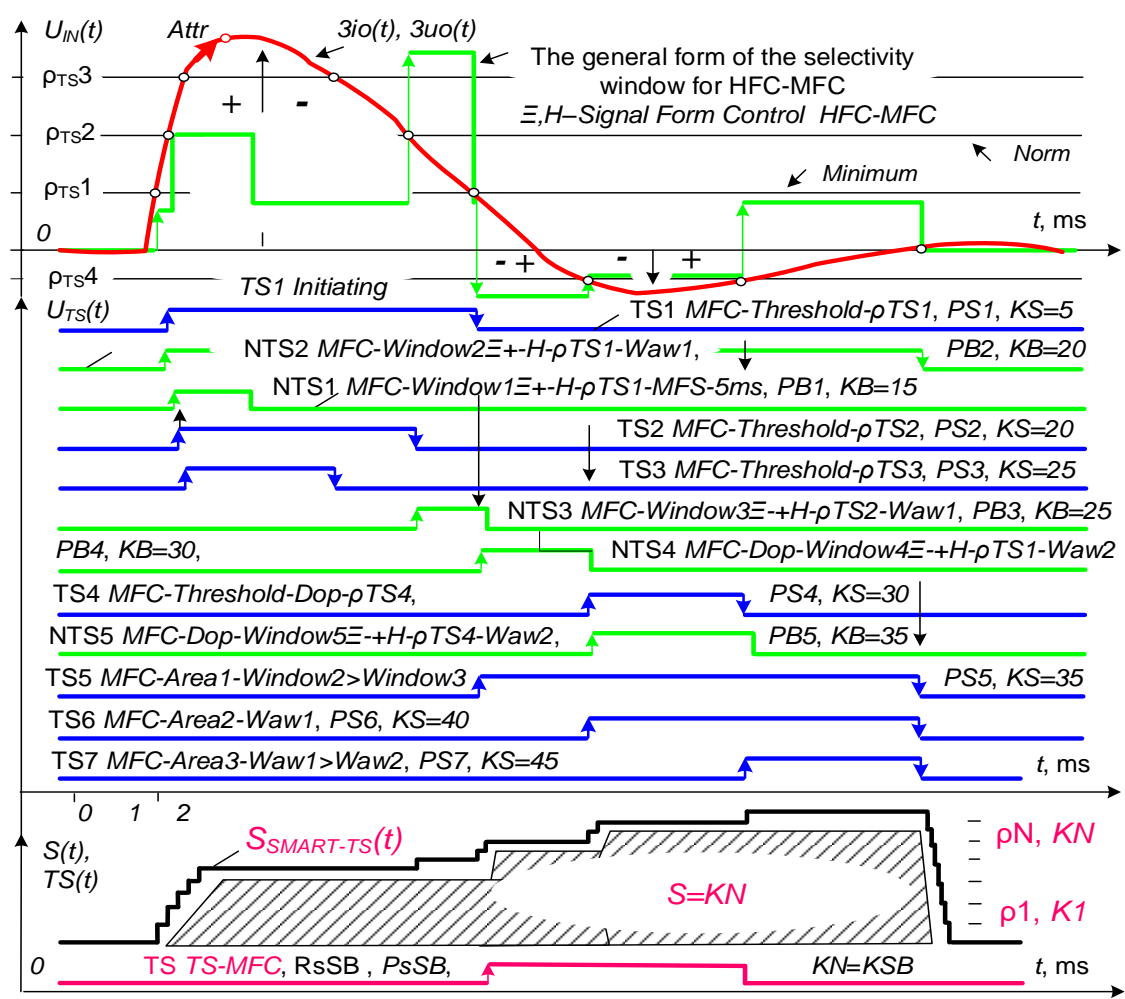

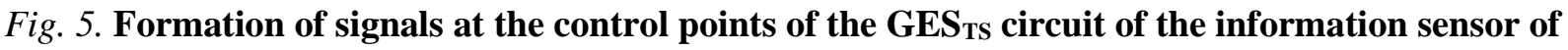
the middle frequencies TS "TS-MFC"

Source: compiled by the authors

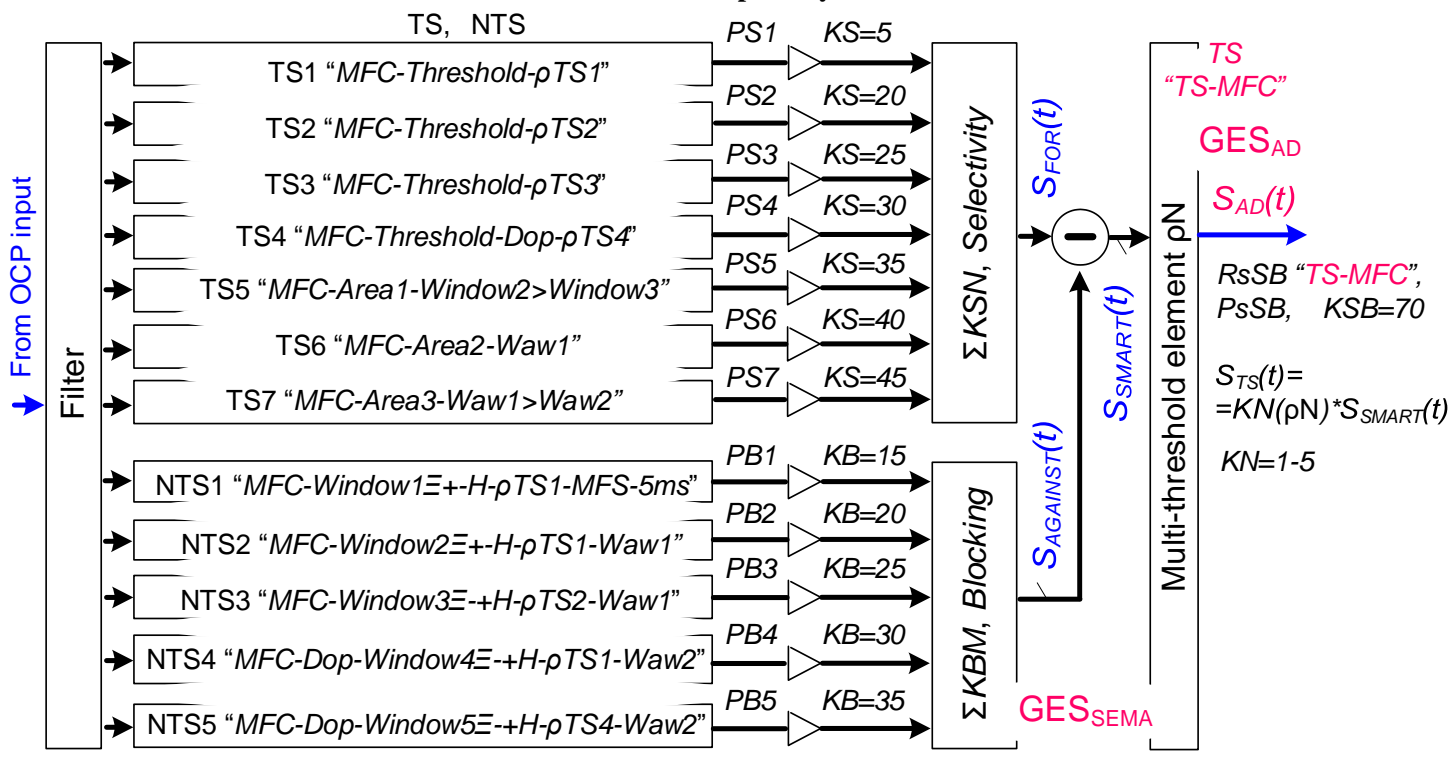

Fig. 6. Semantic automaton scheme SemA in the GESTS scheme of the sensor "TS-MFC" Source: compiled by the authors

In case of further correct development of the first half-wave of the signal $U_{I N}(t)$ in time $t$, the trajectory of the Attr attractor "HFC-MFC" will decrease in amplitude. In this case, additional TS "HFC3io+/-, threshold No. 2", TS "MFC3io+/-, threshold No. 1" are formed.

The values of the thresholds $\rho \mathrm{N}$ for these sensors can be selected according to Fig. 5, for the signal of the damaged portion of the OCP. The values of the $\rho_{\mathrm{TS}} \mathrm{N}$ thresholds are selected based on the maximum sensitivity of the relay. To ensure the quality of recognition, it is predominantly chosen so that the largest possible number of thresholds $\rho_{\mathrm{TS}} \mathrm{N}$ is formed. Signals $U_{I N}(t)$ of undamaged network sections will lead to a signal increase $S(t)$ that is obviously smaller in magnitude and in speed.

As a result, in contrast to the known amplitude detectors, when one TS is formed in the S-detector and only along the rising edge of the input signal $U_{I N}(t)$ during the operation of the S-detector $\mathrm{AD}$, five 
additional TSs are formed. This makes it possible to increase the number of gradations by a factor of 5 , when generating the signal $S(t)$ for this part of the dynamic detection process.

The overall result of the dynamic operation of the $\mathrm{S}$-detector AD with absolute action for the selective frequency components of the HFC-MFC is four: "MFC3io+", TS "MFC3uo-", TS "MFC3io-", TS "MFC3uo-". Modelling shows that for making a decision in a selective relay based on the operation of only the amplitude $\mathrm{AD}$ there are clearly not enough gradations or the amount of information $Q$. For the stable operation of the relay, it is necessary to form a much larger number of gradations. This is realised by the combination of work of the $\mathrm{GES}_{\mathrm{TS}}, \mathrm{GES}_{\mathrm{RPA}}$, GES $_{\text {ASNOM circuits. }}$

\section{SYNTHESIS OF STORAGE ELEMENTARY S-DETECTOR}

The algorithm of cumulative area calculation is necessary to reduce the cost of the error in the operation of the threshold elements $\rho_{\text {TS }} \mathrm{N}$ in the TS sensor " $\Xi+/-"$ (Fig. 4 and 5). The area sensor TS " $\Xi \Xi, \mathrm{H}$ " is an inertial, accumulative structural element which can have a relatively large value of the $K N$ weighting coefficient of the significance of the result, among other selective TS, but less than the synchronous TS. The size of the accumulation area $\int(\Xi, H)$ is estimated by a multi-threshold element $\rho \mathrm{N}$, for example, with five thresholds $\mathrm{N}=5$ and corresponding $K N$ weights. Thus, the $\mathrm{GES}_{\mathrm{TS}}$ scheme with the $\mathrm{G}_{\mathrm{TS}}$ grammar includes a number of time-cumulative elementary TSs, which make it possible to estimate the real area $f(\Xi, \mathrm{H})=\int(\Xi, \mathrm{H})$ of the input dynamic signal. For example, HFC-MFC of the resulting signal $S(t)$.For example, the selective storage sensor TS "Signal Half-Wave Pulse Area" is designed to control the area of the amplitude of the high-frequency component of the HFC-MFC signal of the input coordinate $U_{I N}(t)$ (Fig. 5). This allows the generation of six additional gradations of the signal $S(t)$ for the input coordinates $U 1_{I N}(t), U 2_{I N}(t)$, namely " $3 \Xi, 3 \mathrm{H}$ ". TS " $\Xi \Xi, \mathrm{H}$ " is formed upon exceeding the burnout $f(\Xi, \mathrm{H})=\int(\Xi, \mathrm{H})>\rho \mathrm{N}$.

The criterion of selectivity TS " $\Xi \Xi, H$ " consists of several components, namely:

a) the difference between HFC-MFC on the damaged and not damaged sections of the network;

b) inconsistency of the areas of single impulse noise of the area of the MFC;

c) the influence of the change in the HFC on the area of the MFC becomes significant due to the faster and fading changes in the HFC (analogue of low-frequency filtering during integration).
The result of the algorithm for calculating the $\int(\Xi, H)$ area participates in the formation of volume $Q$ (size and area) of the semantic signal $S_{T S}(t)$.

The method of calculating the real area of the HFC-MFC of the input signal $U_{I N}(t)$ is performed within the time selective window "H" (Fig. 5). It consists of an adder of time samples, for example, from the values of the ADC and the duration of the sync pulses in the Programmable Logic Device. This is equivalent to integrating the HFC-MFC of the input signal $U_{I N}(t)$ over the time window interval "H".

In other words, the method for indirect calculation of the area can consist in controlling the amount of input information to estimate the shape of the $\int \mathrm{HFC}-\mathrm{MFC}$ area by control points, namely, by exceeding the preset values of the two parts of the amplitude $\Xi$-window of selectivity and duration " $\mathrm{H}$ ". The $\Xi, \mathrm{H}$-selectivity windows are calculated proceeding from the values of the thresholds $\rho_{\mathrm{TS}} \mathrm{N}$ of the actually attainable $\int \mathrm{HFC}-\mathrm{MFC}$ area of the input signal $U_{I N}(t)$.

The maximum weight will correspond to the area of the overall selectivity window " $\int \Xi, \mathrm{H}$ ", described by the setting points of the window, namely "Area No. 1", TS1, TS3, NTS "Duration No. 1", TS4, "Duration No. 2". When the window is closed, the result remains about the weight of the coefficient $K N$ of the reached threshold $\rho \mathrm{N}$ when estimating the area of the signal $S_{T S}(t)$.

It is possible to implement control of the signal area $U_{I N}(t)$ within other points of the "Area No. 2", TS1, TS2, NTS "Duration 1" window, and similarly to the points "Area No. 3", TS1, NTS "Duration 1". This implementation is simpler, it uses the existing elements and additional two thresholds " $\Xi, \mathrm{H}$ ” $\rho_{\mathrm{TS}} 4$, $\rho_{\mathrm{TS}} 5$.

\section{EXAMPLES OF SYNTHESIS OF TS SENSORS OF THE INITIAL HIERARCHICAL RECOGNITION LEVEL BASED ON $\Xi, H-W I N D O W S$}

To implement the developed method of selective search SP of the amount of information $Q$ when detecting SceN scenarios, let us consider examples of the synthesis of elementary information sensors TS, in relation to the improvement of known detectors of selective relays $[4,10],[11,13],[14$, 15], [16, 17], [18, 19], [20].

Fig. 5 shows the shape of the amplitude $\Xi, \mathrm{H}-$ window " $\int(\mathrm{HFC}-\mathrm{MFC})$ " and the shaper of the HFCMFC signal $S_{T S-C \Psi C}(t)$.

The application of the considered methods makes it possible to form different information 
sensors TS of absolute action and to obtain in aggregate 12 gradations of the signal $S(t)$, namely:

a) The sensor TS "Amplitude value of $\mathrm{HFC}$ $M F C$ ". Designed to control the magnitude of the amplitude of the high-frequency components HFCMFC of the signal of the input coordinate $U_{I N}(t)$ with the thresholds $\rho \mathrm{N}, \mathrm{N}=1,2 \ldots$ This allows us to form four amplitude gradations of the signal $S(t)$ i.e. TS1 "MFC-Threshold- $\rho$ TS1", TS2 "MFC-ThresholdpTS2", TS3 "MFC-Threshold- $\rho$ TS3", and (optional) TS4 "MFC-Threshold-Dop- $\rho$ TS4".

b) Sensor TS "Rate of rise of the first half-wave of $H F C-M F C$ ". It is intended to control the rate of rise of the front " $\Xi+/-$ " of the pulse signal $U_{I N}(t)$ of the high-frequency components of the HFC-MFC signals of the input coordinate $U_{I N}(t)$ in the form of an amplitude - frequency correspondence (Fig. 7 of Part 1). This allows the separation of the slow frequency component. In other words, the work is equivalent to a low-pass filter but without using the concept of angular frequency $\omega$.

The control is performed using two related $\rho_{\mathrm{TS}} 1, \rho_{\mathrm{TS}} 2$ thresholds and the selectivity $\Xi, \mathrm{H}-$ window. The criterion for the formation of TS is the value of the amplitude of the input signal $U_{I N}(t)$ or the point Attr attractor exceeding two consecutive thresholds $\rho_{\mathrm{TS}} 1, \rho_{\mathrm{TS}} 2$ during the control time $t_{\text {WINDOW. }}$ Additionally, it allows the generation of two gradations of the signal $S(t)$, namely NTS2 "MFCWindow2 $\Xi+-H-\rho T S 1-W a w 1 "$, and TS2 "MFCThreshold- $\rho$ TS2".

Works as a semantic S-filter with a multithreshold decision-making element $\rho \mathrm{N}$. Implements an approach to the description of $U_{I N}(t)$ signals as impulse, single, rare events, combined into semantic situations $S N$, scenario trees $S c e N$, described by recognition trees in the form of GES schemes. Implements part of the GES ASNOM dynamic recognition tree schema (Fig. 1).

The algorithm for the formation of TS "Rate of rise of the First Half-wave" is the following: "If the value of the signal amplitude $U_{I N}(t)$ exceeds the threshold $\rho_{\mathrm{TS}} 1$, then TS1 "MFC-Threshold- $\rho$ TS1" is issued, then this leads to the appearance of TS1, this fact opens the $\Xi$-window NTS2 "MFC-Window2 $\Xi+$ H-pTS1-Waw1". If, during the duration of the window " $\mathrm{H}$ ", the rising edge " $\Xi+/-$ " in the signal $U_{I N}(t)$ continues to develop and exceeds the threshold $\rho_{\mathrm{TS}} 2$, then the window is forcibly closed and TS2 "MFC-Threshold- $\rho_{\mathrm{TS}} 2$ " is issued. In cases of inconsistencies in the development of processes in the OCP and the point attractor Attr by the signal $U_{I N}(t)$ does not correspond to the rate of rise of the parameters $\Xi, \mathrm{H}$-window in amplitude or in the value of the threshold $\rho_{\mathrm{TS}} 2$, then $\Xi, \mathrm{H}$-window NTS2

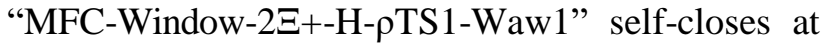
the end of duration " $\mathrm{H}$ " and TS2 "MFC-Threshold$\rho$ TS2" is not issued. Therefore, the resulting TS "TS-MFC" will not be generated. In this case, further recognition of the $S N$ situation will follow a different $S c e N$ scenario.

The duration of the $\mathrm{H}$-window can be determined from Fig. 5. For example, $t_{\text {WINDOW }}=0.5 \mathrm{~ms}$ with a duration of $1 \mathrm{~ms}$ of the first half-wave "WAW1" of the input signal $U_{I N}(t)$, based on the signals from the alarm files of the VCR recorders. This allows the algorithm to be adapted to specific operating conditions.

This algorithm is similarly applied to the formation of the low-frequency TS "LFC Signal Rise Rate". Sequences of $\Xi, H$-selectivity windows are used for each TS, NTS, SN, SceN.

c) The sensor TS "Synchronisation by the presence of HFC-MFC. Blocking $5 \mathrm{~ms}$ ". This was designed to control the correspondence of the amplitude value of the first half-wave of the HFCMFC and the low-frequency LFC 3uo signal $U_{I N}(t)$. In the case of the presence of HFC, but the absence of LFC, the detector is blocked for $5 \mathrm{~ms}$, i.e. until the next possible appearance of the LFC half-period. This makes it possible to control the possibility of the subsequent transient process in the OCP in the next half-period of the LFC " $\Xi+/-$ ", upon the appearance of TS "LFC15V" at the beginning of the transient process.

d) The sensor TS "Rate of Decrease of the First Half-wave of $H F C-M F C$ ". This was designed to control the cut-off of the high-frequency components of the HFC-MFC pulse of the input signal $U_{I N}(t)$ (Fig. $5)$. It allows the formation of one gradation of the signal $S(t)$, namely NTS3 "MFC-Window3 $\Xi-+\mathrm{H}-$ $\rho$ TS2-Waw1". This TS works according to an algorithm similar to the formation of TS "Rate of rise of the first half-wave of the HFC-MFC". TS is built on the basis of control of the cut-off " $\Xi-/+$ " of the pulse input signal with two thresholds $\rho_{\mathrm{TS}} 2$ and $\rho_{\mathrm{TS}} 1$. Slice " $\Xi-/+$ " is formed after passing the maximum value $U_{I N}(t)$. The formation of TS allows us to launch $\Xi$,H-windows of selectivity of control of the second half-wave.

e) The sensor TS "Duration of the First HalfWave HFC-MFC". Designed to control the duration of the first half-wave of the HFC-MFC signal $U_{I N}(t)$. This is an analogue of the sensor for monitoring the frequency of the HFC-MFC signal. The $\Xi, \mathrm{H}$-window of selectivity "Form HFC-MFC" is formed. Formation is started by the appearance of TS "HFCMFC, threshold- $\rho$ TS1". If the signal $S_{T S-C Y C}(t)$ is within the-window duration, i.e. less than the "HFCMFC, threshold- $\rho$ TS3" TS within the H-window, then the TS "HFC-MFC" signal is issued. 
On the front of the first half-wave "MFC3io", the $\Xi, \mathrm{H}$-window "Amplitude window, threshold No. 1 " window is launched. The rate of rise of the edge signal is controlled by the TS sensor "Amplitude Window". The window opens when TS "Exceeding two thresholds in amplitude during the window in time" or " $2 \Xi, H$ " appears. The window controls the duration of the first half-wave in time " $H$ ". This is analogous to the allowable bandwidth of the $U_{I N}(t)$, signal, if it were a stable sinusoidal signal with $\omega$.

In the case of poor-quality formation of the HFC-MFC slice, the slice window " $\Xi-/+$ " is not formed and, as a consequence, this TS with its weighting coefficient $K S N, K B N$ is not added to the general semantic signal $S(t)$. This reduces the magnitude of the signal $S(t)$ but has no overall blocking effect. Furthermore, on the edge of the HFS-MFS signal, the " $\Xi+/-"$ window is launched and TS formation is completed.

During the duration of the H-window, each new sample time (for example, an ADC sample or an internal PLD clock) is assigned its own weighting coefficient $K S N, K B N$. This means that the more such samples there are, the greater the difference in the magnitude of the signal $S_{T S}(t)$. Counting the number of such pulses controls the duration of the "Amplitude" or $\Xi$-window. With a circuit implementation, it can be limited to counting in the event counter, then the time criterion of selectivity is used, i.e. "During such a number of pulses, the selectivity of the criterion will be high".

Furthermore, the trajectory of motion of the point attractor Attr of the signal of the input coordinate $U_{I N}(t)$ decreases and a cut " $\Xi-/+$ " of the pulse of the first half-wave of the HFC-MFC signal $U_{I N}(t)$ is formed.

f) Sensor TS "Rate of rise of the Second Halfwave of $H F C-M F C$ ". Designed to control the magnitude of the amplitude of the second half-wave of the HFC-MFC signal $U_{I N}(t)$. It has the opposite sign in comparison with the first half-wave or " $\Xi-/+$ ", checked by the corresponding zone of the selectivity window. If the second half-wave is greater than the threshold $\rho_{\text {TS }} 4$ of the window " $\Xi$ ", then TS "HFC-MFC, threshold No. 4" is issued.

Additionally, it is possible to organise a similar application of the algorithm for the operation of the $\Xi$-selectivity window AD for the second half-wave of the signal of the input coordinate $3 i o(t)$. Although the second half-wave does not have selectivity for detecting a damaged network section and does not participate in SFD detection according to the GES $S_{\text {RPA }}$ scheme, the general sequence of events during recognition corresponds to the correct development of transient processes in the OCP. Therefore, the second half-wave is additional information for sense recognition. It can be considered that this is a generally synchronised event that follows in dynamics. Since the amplitude of the second halfwave $3 i o(t)$ can be small, then one amplitude threshold TS "MFC3io+/+, half-wave No. 2" can be formed or no TS can be formed.

For networks of short length, the second halfwave turns out to be rather large, therefore, the full algorithm of the selectivity $\Xi, \mathrm{H}$-windows " $2 \Xi, 2 \mathrm{H}$ " is applied. Thus, the volume of information $Q$ will be filled with additional TS, or even four additional TS.

i) Sensor TS "The ratio of the amplitudes of the half-waves of the $H F C-M F C$ ". Designed to control the magnitude of the amplitude of the second halfwave of the input coordinate signal $U_{I N}(t)$, which must be less than the amplitude of the first half-wave of the HFC-MFC component.

To control half-wave No. 2 of the HFC-MFC signal, a selective window " $-\Xi,-H$ " is implemented. The estimation of the presence of the second halfwave is an additional check of the transient signal shape in the OCP. This allows improvement of the quality of the difference between HFC-MFC from single impulse noise. However, in inertial OCPs, the development of only the first half-wave of the HFCMFC signal is possible.

\section{RESULTS OF STUDIES. EXAMPLES OF SIMULATION OF S-DETECTOR OF SCENARIOS IN REAL TIME}

The purpose of CAD modelling performed on the joint SI-model of TS information sensors and the OCP object (Fig. 3 of Part 1), is to synthesise the required quantity and quality of operation of the elementary and general S-detector of SceN, with the elimination of possible causes of errors.

The capabilities of CAD for modelling the processes of obtaining semantic information and the development of built-in blocks of expert systems are used [22, 23], [24, 25], [26]. This makes it possible to test the ability of the algorithm to distinguish some SceN scenarios from others, before using the relay. The ability of the algorithm is assessed by the amount of information $Q$ achieved at the time of the decision to issue a result at all hierarchical levels of recognition in the GES schemes, performed by evaluating the value of the signal $S_{S P}(t)$ to control the attainable and required amount of information $Q$ during the observation time $T_{C H E C K}$ (Fig. 7). For each hierarchical level of recognition, its own value of the amount of information $Q$, sufficient for making a decision at this level, can be achieved. 
To do this, the CAD signals the control sample to the model of the relay algorithm (Fig. 7, Fig. 8 and Fig. 9). Shown are the relative ratios of signals on the time axis $t$ similar to the presentation of the emergency files of the recorders. The accumulated examples of modelling posters with identified errors are used in the synthesis of the selective search SP algorithm of the optimal amount of information $Q$ for making a decision. First of all, we will focus on automatic decision making in cases of conflict $S N$ situations and SceN scenarios.

The scenario SceN "Disconnection of a network section by overcurrent protection of overcurrent protection during the transition of SPG to SC" may not lead to the selection of the damaged section during EFP, but can only indicate the final development of the damage after a certain time (Fig. 7).

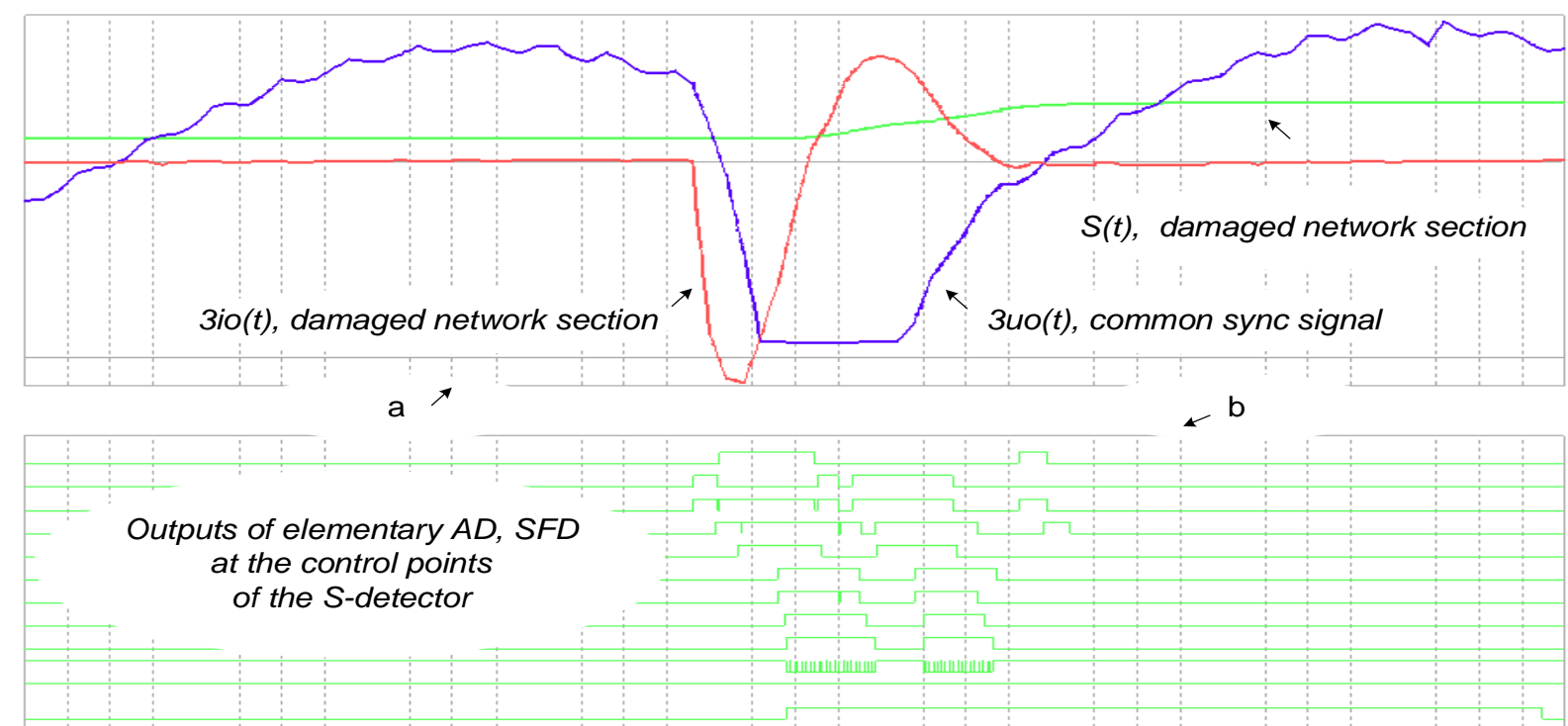

Fig. 7. Modelling of $S N$ in real time of 4 sections $Z 4$.

$S N$ "Breakdown of the EFP in the damaged sections Z":

a - input signals $3 i o(t), 3 u o(t)$, resulting signal $S(t)$;

b - signals at the control points of the $S$-detector

Source: compiled by the authors

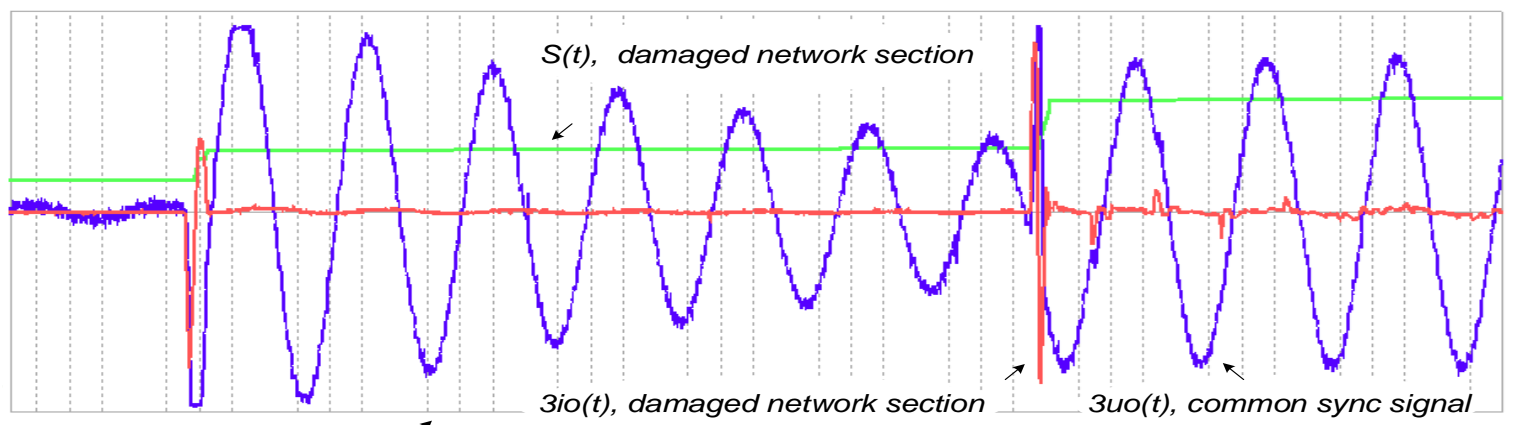

a

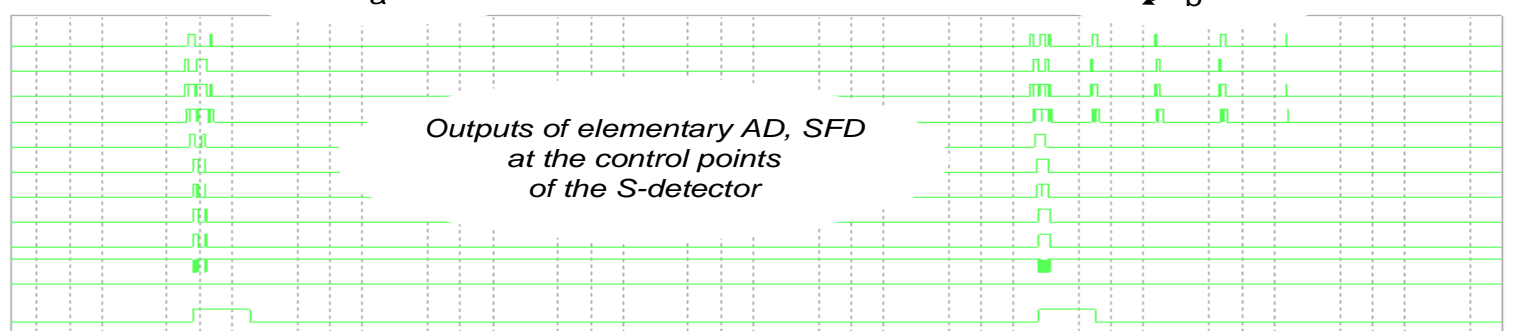

Fig. 8. Modelling of $S N$ in real time of for 4 sections of the $Z N$ network $S N$ "Pecks EFP": a - input signals $3 i o(t), 3 u o(t)$, resulting signal $S(t)$; b - signals at the control points of the S-detector Source: compiled by the authors 
Another of the conflict scenarios for the development of the EFP Sce11 "Self-liquidating breakdown of the EFP and the development of the EFP in the area with weakened insulation" may be as follows (Fig. 8). The development of the scenario is as follows. An initiating $S N$ "Breakdown of the EFP" appears and, for the relay of undamaged network sections, the $S N$ situation "Signal value 3 io is small" is recognised. Furthermore, for undamaged sections of the network, the SFD detector will be blocked. Blocking of the SFD detector is performed by the presence of TS "LFC 3uo" and remains blocked until the end of $S N$ "Checkout time", which is necessary to determine the completion of transients. When the situation $S N$ "EFP breakdown on another network section after s elf- liquidation of the initiating EFP breakdown" appears, the relay remains locked and will not respond to the SN situation "EFP breakdown"; this means that there will be a false relay operation. As a result, the relay will work in the section with the initiating breakdown of the EFP, but the relay will not work, followed by a non-self-liquidating breakdown of the EFP.

The analysis of the conflict scenario Sce11 shows that if the relay is not blocked at the first $S N$ "Breakdown of the SFP", then with the further complex development of the SFP, the set of signals will lead to different variants of non-selective operation of the relay, for example, with $S N$ "Interference", $S N$ "Non-selective actuation with new breakdowns of SFP", $S N$ "Breakdowns of SFP in other sections of the network", etc. As a result, when such scenarios appear, the recognition process ends with the actuation-non-actuation of all relays.

Another conflict scenario, Scel "Unrecognisable", can be a continuation of the scenario according to the recognition tree, namely, Sce1 "A situation $S N$ appears that is not known to the recognition machine, then $S N$ "Unrecognisable" is indicated as the recognition result" (Fig. 9). In the theory of pattern recognition SN, SceN "Unrecognisable" should be considered in principle and the probability of their occurrence can be minimised by continuing to accumulate the amount of information $Q$. This also refers to $S N$ "Not associated with SFP", SN "Third-party processes", and $S N$ "Interference".

\section{THE DISCUSSION OF THE RESULTS. SIMULATION OF THE OPERATION OF THE SCENARIO DETECTION ALGORITHM FOR A SELECTIVE RELAY}

Simulation in CAD revealed errors in the operation of known relays when the detection process is implemented in their structures on the front of the input signals $U_{I N}(t)[4,14]$, $[15,16]$. Fig. 7, Fig. 8 and Fig. 9 show examples of posters for modelling the operation of the synthesised Sdetector algorithm when implementing multipoint non-inertial detection.

If necessary, as the relay algorithm adapts to the specific conditions of the OCP, the components of the $\mathrm{G}$ grammar and the GES scheme are supplemented until a sufficient amount of information $Q$ is processed. The signal $S(t)$ changes roughly, without a distinction of close $S N$ situations or SceN scenarios. This is a sign of insufficient information for recognition. If it becomes necessary to use the internal coordinate of the $\mathrm{OCP}$, then it is necessary to ensure the formation of such information.

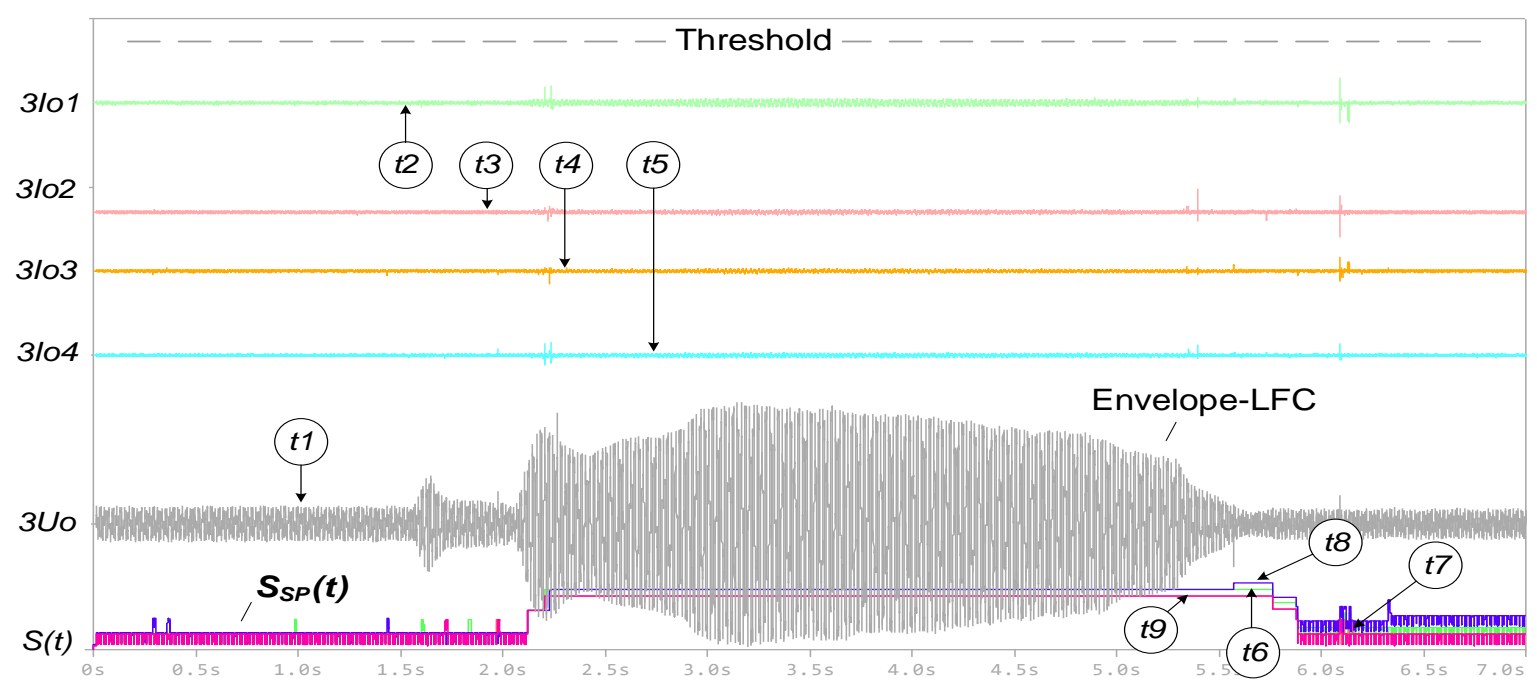

Fig. 9. Modelling of $S N$ in real time $S N$ simulation for $4 Z N$ sections $S N$ "Neutral offset" $t 1$ - 3Uo; $t 2-5$ - signals $3 I o$ for Z1-Z4; t6-9 - sense signals $S(t)$ for Z1-Z4

Source: compiled by the authors 
This requires an additional TS sensor for direct or indirect information acquisition.

The synthesised block diagrams and S-detection algorithms are applied for different frequency loops in a single selective relay algorithm and devices of the entire ASNOM earth fault protection system in medium voltage networks of 6-35 kV (see Part 1) [4, 5], [25, 26]. The ASNOM "LZSC" system includes several devices: the "R-VCR-SP" relay with the SPalgorithm for selectively searching the optimal amount of information $Q$ to determine the damaged network section with the functions of a high-frequency digital recorder VCR, RPA terminal "T-LZSC-ARC" of the measuring cell voltage transformer with the function of an auto-compensator of capacitive currents ARC, and a widget "W-LZSC" for windowed graphic presentation of terminal information on the computer display of the APCS.

\section{EXTENDING THE RESULTS TO OTHER RECOGNITION TASKS}

The SceN scenario detection method uses universal concepts that are applicable to many engineering problems, e.g. the tasks of information processing and decision-making with the issuance of one of a number of answers. This is required in cases of the presence of irregular information events, the selection of selective information, definition of meaning, step-by-step development of events, analysis of transient processes, and others. The Sdetection algorithm with the SP-method and $\Xi, \mathrm{H}$ selectivity windows makes it possible to use it in converting the static formulation of the problem being solved into a dynamic one.

S-detection can be applied to the following applications: coordinate [5, 32], [32] of Part 1], search [28], extreme [5], adaptive [29], optimal [38], expert [29, 35], [16] of Part 1], dispatching [1, 31], [26] of Part 1, economic [3], [25] of Part 1, mathematical modelling [22], [25, 26], [30, 31], [33], [17] of Part 1, functional modelling [21, 22], [18] of Part 1, diagnostics and self-control [23, 26], [22] of Part 1 and others. It can also be applied to tasks regarding meaning recognition in electrical engineering problems: automatic control of technological processes [3, 4], [32, 33], [17] of Part 1, electromagnetic compatibility [23, 35], [19] of Part 1, studies of electrophysical processes [34, 37], [30] of Part 1, electromechanical processes [32, 33], [34, 35], [17] of Part 1, the stability of the systems [20,36], [27] of Part 1, the stability of the electric drive $[22,33],[34,35]$ and the quality of the pulse circuits [35], [23] of Part 1, etc. It is also useful for the tasks of pattern recognition, based on morphological features: linguistic, cochlear, biological [20] of Part 1, medical [28] of Part 1, mechanical [35], optical [36], physicochemical [37], and etc.

\section{CONCLUSIONS}

1. A method of recognising scenarios for the development of semantic, structured information events has been applied to ensure the stability of the operation of the selective protection relay against earth faults in 6-35 kV networks with an arc suppression Petersen's coil. In the synthesised selective relay algorithm, events in all oscillatory circuits of the protected object are monitored. The most selective criterion for the operation of the relay is considered as the main criterion based on the analysis of the coincidence of the first half-waves of the mid-frequency components of the transient signals during single-phase ground faults.

2. The application of the method for controlling the amount of information during the dynamic development of transient processes in smart-grid networks is shown to solve the problem of improving the method of analysis and synthesis of algorithms structures for selective relays against single-phase ground faults. Volume control allows to reduce the cost of error in the operation of the threshold elements of the detectors. The method is based on transmitting data about the amount of information at each transition from the lower hierarchical recognition level to the higher level. Data transmission is performed by selecting the value of the weighting factor from a range of possible values. The choice of the value is carried out according to the condition that the value of the semantic signal reaches the corresponding threshold level.

3. The examples of systematisation of the scenarios in the development of single-phase earth faults are given. Such script structures can be industry-standardised to improve detection algorithms. This will allow comparing the effectiveness of different, known, proposed recognition algorithms.

4. Elementary information sensors of relative, absolute and cumulative actions are synthesised based on the proposed algorithm for recognising scenarios for the development of single-phase earth faults. Examples of filling the amount of information in the implementation of the SP-method of selective search for the optimal amount of information for automatic determination of the damaged section of 
the network are shown. Dynamic recognition is performed uniformly with the help of selectivity $\Xi, \mathrm{H}$-windows, the formation of a semantic signal and then its estimation by weight coefficients with the subsequent transfer of the result to the higher hierarchical levels of recognition. Levels are considered - sensor, relay and terminal.
5. Modelling of the operation of the scenario recognition algorithm, in relation to different hierarchical levels of recognition using samples of high-frequency signals from real emergency files, has been carried out.

\section{REFERENCES}

1. Denysiuk, S. \& Vasylenko, V. "Rank analysis in the problems of optimisation of local power engineering". Quality and Reliability of Technical Systems: Theory and Practice. JVE Book Series on Vibroengineering, August 2018; Vol. 2: 246-254. ISBN 978-609-96036-0-5. ISSN: 2351-5260.

2. Xenias, D., Axon, C., Balta-Ozkan, N. \& Whitmarsh, L. "Scenarios for the Development of Smart Grids in the UK: Literature Review". Project: UK smart grid development. Ref ukerc/wp/es/2014/001. 2014. p. 1-184. - Available from: https://d2e1qxpsswcpgz.cloudfront.net/uploads/2020/03/scenarios-for-thedevelopment-of-smart-grids-in-the-uk.pdf. - [Accessed: March 2020].

3. Podluzhna, N. "The role of economy of knowledge in the post-industrial environment, political sciences, social sciences, business economy, management, międzynarodowy" Instytut innowacji "Naukaedukacjarozwój". International Journal of New Economics and Social Sciences (IJONESS). 2017; No. 1: 127-140. DOI: https://doi.org/10.5604/01.3001.0010.2593.

4. Nikiforov, A. P. "Automatic Control of the Structure of Dynamic Objects in High-Voltage Power Smart-Grid". Automation and Control. Book edited by: C. Volosencu, IntechOpen. London: UK. 2020. p. 127. DOI: https://doi.org/10.5772/intechopen.91664.

5. Nikiforov, A. P. "Solving the Problem of Balancing Algorithms for Relay Protection and Automation Using Game Theory". IEEE 6th International Conference on Energy Smart Systems (ESS), https://www.scopus.com/authid/detail.uri?authorId=57191825673. Kyiv: Ukraine. 2019. p. 177-182. DOI: https://doi.org/10.1109/ESS.2019.8764238.

6. Obabkov, V. K. \& Nikiforov, A. P. "Accuracy of automatic trimming frequency of free oscillations in symmetrical networks with resonantly earthed neutral". Publ. Elektrichestvo.. https://www.scopus.com/authid/detail.uri?authorId=57191825673. $\quad 1996 ; \quad$ No. $\quad 12: \quad 8-16$. DOI: https://doi.org/10.13140/RG.2.1.4204.7127.

7. Sivokobylenko, V. F., Nikiforov, A. P. \& Zhuravlov, I. V. Detecting development scenarios of dynamic events in electric powernetworks smart-grid. Part 1 "Method". Applied Aspects of Information Technology. Publ. Nauka $i$ Tekhnika. Odessa: Ukraine. 2021; Vol. 4 No. 3: 219-234. DOI: https://doi.org/10.15276/aait.03.2021.1.

8. Petrov, E. M. \& Solovyov, I. V. "Control of plunger arc-suppressing reactors when combining bus sections". Publ. Elektrika. Device for universal complex earth-fault protection for 6-35 kV networks, http://www.nait.ru/journals/number.php?p_number_id=904. 2008; No. 8: 21-24.

9. Shkrabets, F., Ostapchuk, A. \& Akulov, A. "Automatic compensation of single-phase current components to earth in quarry networks with a voltage of $6 \mathrm{kV}$ ". Explosion-proof Electrical Equipment. 2011; No. 1: 193-200.

10. Huang, S. "Research on Relay Protection Technology Based on Smart Grid". IOP Conf. Ser.: Earth Environ. Sci. 714 042084. IOP Conference Series: Earth and Environmental Science (ESMA). IOP Conf. Ser.: Earth Environ. Sci. 714 042084. 2020; Vol. 714,3. Green Energy and Power Engineering DOI: https://doi.org/10.1088/1755-1315/714/4/042084.

11. Schweitzer, E., Kasztenny, B., Guzmán, A., Skendzic, V. \& Mynam, M. "Speed of line protection - can we break free of phasor limitations". Proc. 68th Annu. Conf. Protective Relay Engineers. 2015. p. 448-461. DOI: https://doi.org/10.1109/CPRE.2015.7102184.

12. Papaspiliotopoulos, V., Korres, G., Kleftakis, V. \& Hatziargyriou, N. "Hardware-in-the-loop design and optimal setting of adaptive protection schemes for distribution systems with distributed generation". IEEE Transactions on Power Delivery. 2017; Vol. 32 No. 1: 393-400. DOI: https://doi.org/10.1109/ PESGM.2017.8274178.

13. Saleem Dawood, R., Pillai, G. \& Al-Greer M. "Fuzzy Logic Based Scheme for Directional Earth Fault Detection and Classification". 53rd International Universities Power Engineering Conference (UPEC). 2018. p. 1-6. DOI: https://doi.org/10.1109/UPEC.2018.8542006. 
14. Sopel, M., Grebchenko, N. \& Pylypenko, Y. "Fault location method development at lines with trilateral feed". IEEE 7th International Conference on Energy Smart Systems (ESS). Wroclaw: Poland. 2020. p. 238-242. DOI: https://doi.org/10.1109/ESS50319.2020.9160140.

15. Grebchenko, N. , Maximchuk, V. \& Pylypenko, Y. "The method of determining parameters of single-phase fault in network with isolated neutral". 2nd International Conference on Intelligent Energy and Power Systems (IEPS). Conference Proceedingsthis link is disabled. 2016; 7521880: 1-3. DOI: https://doi.org/10.1109/IEPS.2016.7521880.

16. Syvokobylenko, V. F. \& Lysenko, V. A. "Microprocessor selective protection from the phase to the earth fault in electric networks with Petersen coil in neutral". Technical Electrodynamics. 2019; No. 2: 5462. DOI: https://doi.org/10.15407/techned2019.02.054.

17. Alkaran, D., Vatani, M., Sanjar, M., Gharehpetian, G. \& Yatim, A. "Overcurrent relays coordination in interconnected networks using accurate analytical method and based on determination of fault critical point". IEEE Transactions on Power Delivery. 2015; Vol. 30 No. 2: 870-877.

18. Shi, Z., Chen, H., Yu, J. \& Ding, X. "Research on coordination between single Phase-to-Ground fault protection equipment and distribution terminal unit". IEEE 4th Conference on Energy Internet and Energy System Integration (EI2). 2020. p. 2053-2057. DOI: https://doi.org/10.1109/ EI250167.2020.9346691.

19. Dudarev, L. E. \& Zubkov, V. V. "Device for universal complex earth-fault protection for 6-35 kV networks". Promyshlennaya Energetika. 1982; No. 4: 36-38.

20. Voloshyn, S., Omelchuk, A., Tarasiuk, O., Titova, L. \& Gumenyuk, Y. "Simulation of criteria for selection of remote protection settings with remote starting in lines with distributed sources". IOP Conference Series: Materials Science and Engineering. 2021; Vol. 1030 No. 1.

21. Tiutiunnyk, F., Kozyrskyi, V., Tugai, Y. \& Prystupa, A. "The improving control system of distributed generation sources taking into account their dynamic parameters". IEEE 38th International Conference on Electronics and Nanotechnology (ELNANO). Proceedings. Kyiv: Ukraine. 2018. p. 474-477. DOI: https://doi.org/10.1109/ELNANO.2018.8477534.

22. Zablodskiy, M., Pliuhin, V. \& Chuenko, R. "Simulation of induction machines with common solid rotor". Tekhnichna Electrodynamics. 2018; No. 6: 42-45. DOI: https://doi.org/10.15407/ techned2018.06.042.

23. Larin, V., Chichikalo, N., Kardo, A. \& Larina, K. "Integrated intellectual approach to the diagnostics of defects of operations of induction motors". IEEE 15th International Conference on Computer Sciences and Information Technologies (CSIT). Zbarazh: Ukraine. 2020. p. 352-356. DOI: https://doi.org/10.1109/CSIT49958.2020.9322004.

24. Namdari, F. \& Salehi, M. "High-speed protection scheme based on initial current traveling wave for transmission lines employing mathematical morphology". IEEE Trans.Power Del.2017; Vol.32 No.1:246-253.

25. Zaporozhets, Y., Batechko, N., Shostak, S., Shkoda, N. \& Dibrivna, E. "Features of mathematical modelling of electromagnetic processing of bulk materials". Eastern European Journal of Enterprise Technologies. 2020; Vol. 3 No. 5(105): 49-59. DOI: https://doi.org/10/15587/1729-4061.2020.206705.

26. Savchuk, O., Ladanyuk, A. \& Gritsenko, N. "Cognitive approach to modelling and managing semistructured organisational and technological systems (situations)". Eastern-European Journal of Enterprise Technologies. 2009; Vol. 2, No. 3(38): 14-18. - Available from: http://journals.uran.ua/eejet/article/view/5888. - [Accessed: March 2020].

27. Nikiforov, A. P. "Application of the theorem of 'about the unity of the structural description of rpa devices' for the simulation of a power network smart-grid". 3rd Renewable Energy and Green Technology International Confer. (REEGETECH). Journal of Telecommunication. Electronic and Computer Engineering, https://www.scopus.com/authid/detail.uri?authorId=57191825673. Jakarta: Indonesia. 2017; Vol. 9 No. 1-5: 39-48.

28. Nikiforov, A. P. "The through simulation of devices on the basis of the structural linguistic method". 7th International Conference-Workshop Compatibility and Power Electronics (CPE). https://www.scopus.com/authid/detail.uri?authorId=57191825673, https://publons.com/researcher/2303561/a ndrey-petrovich-nikiforov. Tallinn: Estonia. 2011. p. 50-55. DOI: https://doi.org/10.1109/ CPE.2011.5942206.

29. Kaplun, V., Shtepa, V. \& Makarevych, S. "Neural Network Modelling of Intelligent Energy Efficiency Control in Local Polygeneration Microgrid with Renewable Sources". IEEE KhPI Week on 
Advanced Technology. KhPI Week, Conference Proceedings. 2020. p. 98-102. DOI: https://doi.org/10.1109/KhPIWeek51551.2020.9250130.

30. Sheina, A. "Simulation of transient process in generators for equivalent circuit with different mutual inductance among loops". The Advanced Science Open Access Journal. United States: 2012; No. 5:105-109.

31. Larshin, V., Lishchenko, N., Babiychuk, O. \& Pitel', J. "Computer-aided design and production information support". Herald of Advanced Information Technology. Publ. Nauka i Tekhnika. Odessa: Ukraine. 2021; Vol. 4 No. 2: 111-122. DOI: https://doi.org/10.15276/hait.02.2021.1.

32. Tolochko, O., Kalugin, D., Palis, S. \& Oshurko, S. "Field weakening control for induction motors based on copper and iron losses minimization". Applied Aspects of Information Technology. Publ. Nauka $i$ Tekhnika. Odessa: Ukraine. 2020; 3 (2): 44-57. DOI:https://doi.org/10.15276/aait.02.2020.3.

33. Tolochko, O. \& Rozkariaka, P. "Asymmetric reference trajectories for energy efficiency position electric drives". 10th International Conference on Electrical Power Drive Systems (ICEPDS). ISBN: 9781538647141. United States: 2018; Vol.16 No.3:1-7. DOI: https://doi.org/10.1109/ ICEPDS.2018.8571602.

34. Shurub, Y., Vasylenkov, V. \& Tsytsyurs'kyy, Y. "Investigation of the properties of the combined circuit of single-phase switching on of asynchronous electric drive of pumping units". Tekhnichna Electrodynamics. 2018; No.6: 50-53. DOI: https://doi.org/10.15407/techned2018.06.050.

35. Shavolkin, O., Kaplun, V. \& Shvedchykova, I. "Improvement of the single-phase multifunctional converter for combined electric power system". IEEE 6th International Conference on Energy Smart Systems (ESS) Proceedings. e-ISBN: 978-1-7281-2160-4. ISBN:978-1-7281-2161-1. Kyiv: Ukraine. 2019. p. 213-218. DOI: https://doi.org/10.1109/ESS.2019.8764216.

36. Lezhnyuk, P., Cheremisin, N. \& Cherkashina, V. "Improving the efficiency of managing the modes of electrical networks based on monitoring the parameters of overhead lines and the environment". Elektricheskiye Seti $i$ Sistemy. Kyiv: Ukraine. 2012; No. 5: 39-46. - Available from: http://electromagazine.com.ua/ web\&systems.php?number=2\&year_id=12. - [Accessed: March 2020].

37. Lyubimenko, E. \& Goltsova, M. "The Form Changing of Palladium Plate Induced by Small OneSide Hydrogen Impacts”. Metallophysics and Advanced Technologies. 2014; Issue 2 Vol. 36 No. 2: 247-258. DOI: https://doi.org/10.15407/mfint.36.02.0247.

38. Bodunov, V., Kulko, T., Prystupa, A. \& Gai, A. "Topological task of distributed generation placement using a Pareto optimization". IEEE 3rd International Conference on Intelligent Energy and Power Systems (IEPS). Proceedingsthis link is disabled. Kharkiv: Ukraine. 2018. p. 183-188. DOI: https://doi.org/10.1109/IEPS.2018.8559502.

Conflicts of Interest: the authors declare no conflict of interest

Received $\quad 08.02 .2021$

Received after revision 11.03.2021

Accepted 16.03.2021

DOI: https://doi.org/10.15276/hait.04.2021.2

УДК 004.922

\title{
Детектування сценаріїв розвитку динамічних подій в електроенергетичних мережах смарт-грид. Частина друга «Селективний захист»
}

\author{
Віталій Федорович Сивокобиленко ${ }^{1)}$ \\ ORCID: https://orcid.org/0000-0002-7720-0540; svf1934@ gmail.com. Scopus Author ID: 6603906155 and 55553493200 \\ Андрій Петрович Нікіфоров 2$)$ \\ ORCID: https://orcid.org/0000-0002-3724-430; a.p.nikiforov@i.ua. Scopus Author ID: 57191825673
}


Іван Вадимович Журавльов

ORCID: https://orcid.org/0000-0003-4879-4666; ivanvzhuravlov@gmail.com 1) Донецький національний технічний університет, 2, площа Шибанкова. Покровськ, Донецька область, 85300, Україна

2) Навчально-науковий інститут енергетики, автоматики і енергозбереження. Національний університет біоресурсів і природокористування України, вул. Героїв Оборони, 12, корпус 8. Київ, 03041,

3) SICAME SAS Франція, 39, пр. дю Міді, місто Сент-Сорнен Лавольпс, Франція

\section{АНОТАЦІЯ}

При реалізації концепцій розвитку електроенергетики Smart-Grid, Цифрова підстанція, Аутсорсинг послуг актуальним $\epsilon$ завдання забезпечення стійкості роботи пристроїв релейного захисту та автоматики. Завдання вирішується відповідно до структурного-інформаційного SI-методу, що розробляється. Пропонується спосіб селективного пошуку (SP) оптимального обсягу структурованої інформації для автоматичного прийняття рішень. У статті розглядається алгоритм розпізнавання сценаріїв розвитку значеннєвих подій, який включений до SP-способу. Алгоритм застосовується однаково до всіх ієрархічних рівнів розпізнавання, виходячи із цілей прийняття рішення на старшому рівні. Контроль послідовності інформаційних подій виконується в динаміці проходження подій по одному шляху зі всіх взаємозв'язків відповідно до SIмоделі. В Частині 1 показана спільна SI-модель, що складається із дерева формування в динамічному об'єкті та дерева розпізнавання в пристроях. Дано теоретичний опис алгоритму за допомогою амплітудного та тимчасового $(\Xi, \mathrm{H})$ вікон селективності у загальній структурній схемі S-детектування. Показано застосування способу різних ієрархічних рівнів розпізнавання. Результат прийняття рішення видається у двох формах подання. А саме. За допомогою єдиного смислового сигналу для вказівки на групу результатів. Через заповнення таблиці послідовності появи розпізнаних елементарних інформаційних складових. У Частині 2 показано застосування SP-способу на різних ієрархічних рівнях розпізнавання для синтезу селективного реле, в якому реалізується алгоритм пошуку пошкодженої ділянки мережі при однофазних замиканнях на землю у розподільних мережах 6-35 кВ із котушкою Петерсена. Вказано причини нестійкої роботи алгоритмів відомих селективних реле, виходячи із понять розпізнавання сценаріїв. Розглянуто вдосконалення структури селективного реле, що працює на основі критерію контролю збігу перших напівхвиль середньочастотних складових сигналів перехідних процесів. Наведено приклади синтезу елементарних детекторів абсолютної, відносної та накопичувальної дії стосовно селективного реле, що дозволяють наповнити обсяг інформації для загального Sдетектування. Виконано моделювання роботи синтезованого S-детектора на сигналах реальних аварійних файлів природного розвитку ушкоджень ізоляції фази мережі та моделювання штучних сценаріїв подій у математичній SI-моделі.

Ключові слова: релейний захист; автоматизація; інтелектуальна мережа; захист від однофазних замикань на землю; семантичний сигнал; структурно-інформаційний метод

\section{ABOUT THE AUTHORS}

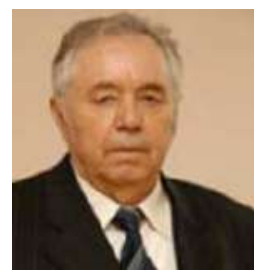

Vitaliy F. Sivokobylenko - D.Sc. (Eng), Professor, Department of "Electrical Engineering”. Donetsk National Technical University. 2, Shibankova Square. Pokrovsk, 85300, Ukraine

ORCID: https://orcid.org/0000-0002-7720-0540; svf1934@gmail.com. Scopus Author ID: 6603906155 and 55553493200

Research field: Maths modelling; transient processes; increasing reliability; power plant needs; relay protection

Віталій Федорович Сивокобиленко - доктор технічних наук, професор, професор кафедри «Електрична інженерія» Донецький національний технічний університет, пл. Шибанкова, 2. Покровськ, 85300, Україна

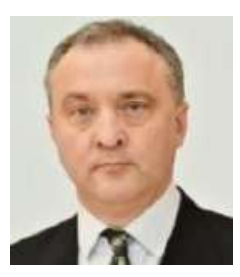

Andrey P. Nikiforov - D.Sc. (Eng), Associate Professor, Department of "Power Supply" of Education and Research Institute of Energetics, Automation and Energy Efficiency (NNI EAE) National University of Life and Environmental Sciences of Ukraine, (NUBiP). 12, Vul. Heroyiv oborony. Kyiv, 03041, Ukraine

ORCID: https://orcid.org/https://orcid.org/0000-0002-3724-430; a.p.nikiforov@i.ua. Scopus Author ID: 57191825673

Research field: Relay protection; capacitive current compensation; smart grid; single-phase earth faults;

distribution networks; pattern recognition

Андрій Петрович Нікіфоров - доктор технічних наук, доцент, доцент кафедри Електропостачання Навчальнонаукового інституту енергетики, автоматизації та енергоефективності (NNI EAE) Національного університету біоресурсів та природокористування України (НУБіП). вул. Героїв оборони, 12. Київ, 03041, Україна

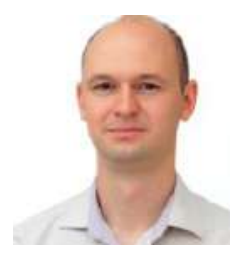

Ivan V. Zhuravlov - Product manager (Eng). Duties: Product lifecycle management, global market strategy development, gathers and analyses market and competition research data, New product development assistant SICAME SAS France, 39, Av. du Midi, St. Sornin Lavolps, France

ORCID: https://orcid.org/0000-0003-4879-4666; ivanvzhuravlov@ gmail.com

Research field: Relay protection; smart grid; single-phase earth faults; distribution networks

Іван Вадимович Журавльов - Менеджер із продукту. Обов'язки: управління життєвим циклом продукту, розробка глобальної ринкової стратегії, збір та аналіз даних із дослідження ринку та конкуренції, помічник у розробці нових продуктів

SICAME SAS France, 39, пр. дю Міді, місто Сент-Сорнен Лавольпс, Франція 